УДК 338:631.92

https://doi.org/10.33296/2707-0654-9(18)-16

\title{
ПИЩЕНКО ОЛЕКСАНДР
}

кандидат економічних наук, Національний університет «Чернігівська політехніка», м. Чернігів, Україна

ORCIDiD: http://orcid.org/0000-0353-8238-8544

\section{КОНЦЕПТУАЛЬНО-МЕТОДОЛОГІЧНІ АСПЕКТИ ФОРМУВАННЯ СТРАТЕГІЇ ЗАБЕЗПЕЧЕННЯ ЕКОЛОГО-ЕКОНОМІЧНОЇ БЕЗПЕКИ АГРАРНОГО СЕКТОРУ}

Анотація. Запропоновано складові стратегії еколого-економічної безпеки аграрного сектору в Україні, ключовою метою якої $є$ визначення моделі дій і засобів системи забезпечення еколого-економічної безпеки аграрного сектору, розробка основних напрямів, форм, методів та інструментів досягнення стратегічних цілей; аргументовано, що дана стратегія повинна включати п'ять розділів (1. Преамбула. 2. Загальні положення. 3. Мета, основні напрями i завдання. 4. Механізми. 5. Індикатори), реалізація яких передбачає об'єднання зусиль владних структур та суспільства на рівні держави, регіонів і місцевого самоврядування. Для реалізації стратегії необхідно виконати комплекс завдань: визначити основні параметри екологічно безпечного стану аграрного сектору; ідентифікувати пріоритети еколого-економічної політики щодо цілей забезпечення еколого-економічної безпеки аграрного сектору; обгрунтувати шляхи і способи досягнення завдань забезпечення еколого-економічної безпеки аграрного сектору; сформувати комплекс заходів, що забезпечують досягнення визначених цілей i завдань; визначити необхідні ресурси для реалізації визначених завдань, а також умов і чинників, що забезпечують найбільшу ефективність їх використання; забезпечити ефективну організацію моніторингу реалізації документів стратегічного планування в забезпеченні екологоекономічної безпеки аграрного сектору. Механізм реалізації стратегії передбачає об'єднання зусиль владних структур та суспільства на рівні держави, регіонів і місцевого самоврядування у напрямку координації стратегії 3 чинними комплексними цільовими програмами та здійснення моніторингу іiі реалізації на основі встановлення цільових показників. Інформаційна та інформаційно-аналітична підтримка реалізації цієї стратегії здійснюється за координуючої ролі відповідного Міністерства за рахунок залучення інформаційних ресурсів зацікавлених органів державної влади та державних наукових установ.

\footnotetext{
(C) Українська інженерно-педагогічна академія

(C) ГО «Школа адаптивного управління сочіально-педагогічними системами»

(C) Пищенко $O$.
} 
Ключові слова: аграрний сектор, еколого-економічна безпека, стратегія, забезпечення, державна політика.

Вступ. Основу державної політики складають стратегічні орієнтири, які повинні закріплюватися відповідними державно-правовими структурами. Зважаючи на основні вимоги сучасності щодо розвитку аграрного сектору, доцільною $є$ розробка стратегії щодо його еколого-економічної безпеки. Враховуючи погляди науковців сучасності, під стратегією безпеки аграрного сектору слід розуміти сукупність найбільш значущих рішень, спрямованих на забезпечення відповідного рівня безпеки у контексті реалізації державних цільових програм. Тобто, така стратегія $\epsilon$ довгостроковим прогнозом комплексного розв'язання проблеми збалансованого, з урахуванням екологоекономічних аспектів, розвитку аграрного сектору та поліпшення загального стану еколого-соціо-економічної системи аграрного сектору. У рамках цього документа відпрацьовуються основні шляхи структурної трансформації аграрної політики та розміщення продуктивних сил, що враховують імперативи збалансованого розвитку та забезпечення еколого-економічної безпеки аграрного сектору.

Аналіз останніх досліджень і публікацій. В дослідженнях вітчизняних вчених, присвячених проблемам забезпечення еколого-економічної безпеки аграрного сектору, в більшій мірі досліджується стан речей, що склався в даній сфері, і в меншій мірі надаються пропозиції з іiі удосконалення.

Управлінські аспекти забезпечення еколого-економічної безпеки аграрного сектору розроблялися у працях: В. Борщевського, Б. Буркинського, Т. Галушкіна, І. Гайдуцького, О. Манойленка, Л. Мельник, А. Никифорова, В. Потапенко, В. Реутова, В. Русана, П. Саблук, М.Скорик, О. Ходаківської та ін.

Незважаючи на широкий спектр напрямів дослідження особливостей забезпечення еколого-економічної безпеки аграрного сектору, у працях зазначених учених практично не знайшли відображення питання розробки 
ефективного інструментарію інституційного регулювання еколого-економічної безпеки аграрного сектору.

Цілі даної наукової роботи - представити наукові підходи до формування державної стратегї еколого-економічної безпеки аграрного сектору в Україні.

Виклад основного матеріалу дослідження. Стратегія екологоекономічної безпеки аграрного сектору в Україні має стати базовим документом стратегічного планування у напрямку розвитку еколого-соціоекономічної системи забезпечення еколого-економічної безпеки аграрного сектору і визначає комплекс взаємопов'язаних пріоритетів, цілей, завдань та заходів. Базовою метою стратегії $є$ визначення моделі дій і засобів системи забезпечення еколого-економічної безпеки аграрного сектору та розробка основних напрямів, форм, методів і засобів досягнення стратегічних цілей. Для реалізації поставленої мети необхідно виконати комплекс завдань: визначити основні параметри екологічно безпечного стану аграрного сектору; ідентифікувати пріоритети еколого-економічної політики щодо цілей забезпечення еколого-економічної безпеки аграрного сектору; обгрунтувати шляхи і способи досягнення завдань забезпечення еколого-економічної безпеки аграрного сектору; сформувати комплекс заходів, що забезпечують досягнення визначених цілей і завдань; визначити необхідні ресурси для реалізації визначених завдань, а також умов i чинників, що забезпечують найбільшу ефективність їх використання; забезпечити ефективну організацію моніторингу реалізації документів стратегічного планування в забезпеченні екологоекономічної безпеки аграрного сектору.

Результати проведеного дослідження дали можливість запропонувати власну структуру і зміст стратегії еколого-економічної безпеки аграрного сектору в Україні:

(C) Українська інженерно-педагогічна академія

(C) ГО «Школа адаптивного управління сочіально-педагогічними системами»

(C) Пищенко $O$. 
1 розділ. Преамбула. Її зміст полягає у короткому викладенні актуальності даної стратегіï та іï зв'язку з існуючими нормативно-правовими документами, визначенні поняття «стратегія еколого-економічної безпеки аграрного сектору». Таке визначення має виходити з розуміння правильного співвідношення ролі та змісту понять «еколого-економічна безпека» та «державний механізм регулювання еколого-економічної безпеки аграрного сектору».

2 розділ. Загальні положення. Даний розділ стратегії передбачає обгрунтування бачення місця державної політики еколого-економічної безпеки аграрного сектору у контексті національної еколого-економічної політики та у загальному змісті діяльності суб’єктів аграрного сектору щодо забезпечення необхідного рівня безпеки в державі. У свою чергу важливим видається формулювання державної політики еколого-економічної безпеки аграрного сектору, як інтеграційного елемента державної еколого-економічної політики.

Важливим моментом змісту є також визначення основних факторів впливу, як внутрішніх, так і зовнішніх, на стан еколого-економічної безпеки аграрного сектору в Україні, що дозволить враховувати впливи процесів глобального характеру та специфічні риси соціально-еколого-економічної ситуації в країні. За цих умов визначаються основні вихідні правила, тобто принципи діяльності, спрямовані на забезпечення декларованого Конституцією України рівня еколого-економічної безпеки для усіх громадян.

3 розділ. Мета стратегії та основні напрями i завдання досягнення еколого-економічної безпеки аграрного сектору. Конкретизація у межах основних напрямів здійснюється за рахунок формулювання низки завдань діяльності суб’єктів аграрного сектору та політики держави щодо забезпечення потрібного рівня еколого-економічної безпеки.

\footnotetext{
(C) Українська інженерно-педагогічна академія

(C) ГО «Школа адаптивного управління сочіально-педагогічними системами»

(C) Пищенко $O$.
} 
4 розділ. Механізми (інструментарій). До них можуть бути віднесені нормативно-правові, організаційні, економічні, фінансові, інформаційні та інші механізми.

5 розділ. Індикатори. Відповідні показники досягнення необхідного рівня еколого-економічної безпеки аграрного сектору. Проведення необхідної експертизи та оцінки на основі даних моніторингу дозволить говорити про ступінь наближення до результатів, що очікуються. В даному розділі передбачається визначення можливостей для розробки на загальних засадах пропонованої стратегії цільових програм, як національного, так і регіонального рівня. При цьому регіональні програми можуть розглядатися у якості вихідних, інтеграційних для програм місцевого рівня.

Структуру стратегії еколого-економічної безпеки аграрного сектору представлено на рис. 1.

Виходячи із запропонованої на рис. 1 схематичної інтерпретації складових стратегії еколого-економічної безпеки аграрного сектору в Україні доцільним є їі деталізація вже на змістовному рівні.

I. Актуальність розробки та впровадження стратегії еколого-економічної безпеки аграрного сектору в Україні обумовлена тим, що зміни, які відбувалися 3 моменту набуття Україною незалежності у сфері охорони навколишнього природного середовища, користування природними ресурсами та забезпечення еколого-економічної безпеки аграрного сектору, не змінили на краще екологоекономічний стан.

Акцент на соціально-економічні реформи в країні призвів до зменшення уваги до питань еколого-економічної політики, послаблення ролі відповідних інституцій та їх контролюючих функцій у контролі за дотриманням екологоекономічних вимог.

Суттєвим недоліком вказаного періоду державної розбудови стала відсутність системності у нормативно-правовому забезпеченні діяльності

\footnotetext{
(C) Українська інженерно-педагогічна академія

(C) ГО «Школа адаптивного управління сочіально-педагогічними системами»

(C) Пищенко $O$.
} 
суб’єктів аграрного сектору щодо виконання вимог еколого-економічної безпеки в державі.

На жаль, в сучасних умовах відсутні відповідні нормативно-правові акти, які мають бути орієнтовані на реалізацію національної політики щодо забезпечення еколого-економічної безпеки аграрного сектору в Україні. Відсутність таких законодавчих актів певною мірою може бути компенсована, на час, необхідний для законотворчості, поширеним розумінням стратегії еколого-економічної безпеки аграрного сектору в Україні. Природно, що все означене сприяло суттєвому зниженню ефективності діяльності відповідних управлінських структур на національному, регіональному і місцевому рівнях.

Слабкість та недостатня ефективність існуючої системи регулювання у питаннях забезпечення еколого-економічної безпеки населення України, не завжди своєчасні та послідовні структурні реформи, повільна модернізація технологічних процесів на тлі зростання показників економічного розвитку призвели до високих рівнів забруднення та підтримки старих, неефективних підходів до використання енергетичних та природних ресурсів, низькою якістю аграрної продукції, неефективними методами боротьби з відходами аграрного сектору тощо. Одним з дієвих та ефективних заходів держави у цій ситуації може бути визначена розробка та впровадження стратегії еколого-економічної безпеки аграрного сектору в Україні.

Запропонована нами структура стратегії грунтується на основних положеннях Закону України «Про охорону навколишнього природного середовища» та Закону України «Про Основні засади (стратегію) державної еколого-економічної політики України на період до 2020 року». 


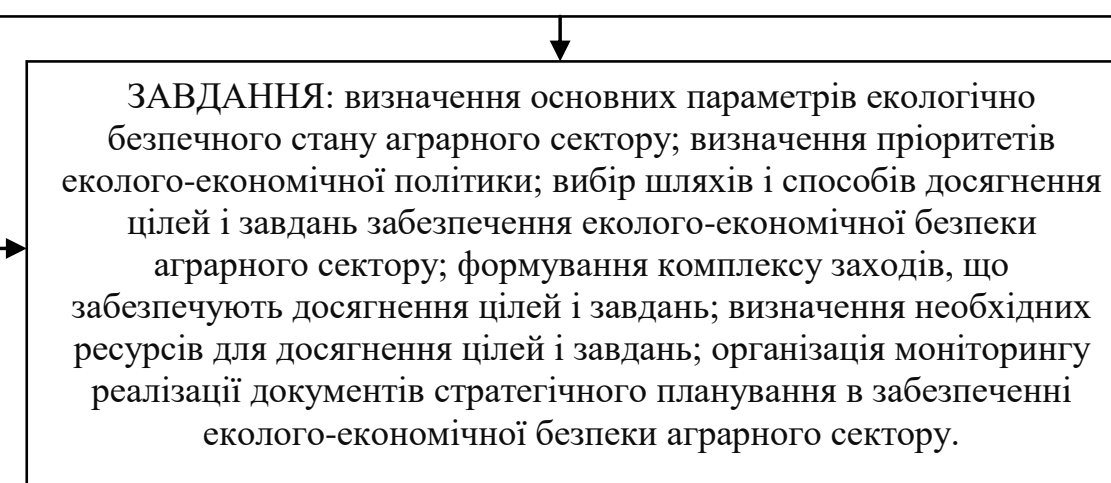

ПРИНЦИПИ: забезпечення рівноваги між динамічними аграрною i еколого-економічною системами та компонентами природи; інтеграція економічного й екологічного підходів до розвитку аграрного сектору; забезпечення відповідальності суб'єктами аграрного сектору за раціональне та ефективне використання природних ресурсів, їх збереження і захист від деградації; реалізація стратегічних напрямів має здійснюватися з урахуванням розмежування повноважень елементів між рівнями системи забезпечення еколого-економічної безпеки аграрного сектору з урахуванням координації їх діяльності; своєчасність і відповідність вжиття запропонованих заходів; своєчасна адаптація з урахуванням мінливих стратегічних пріоритетів щодо підвищення рівня і якості життя населення; прийняття рішення у сфері стратегічного планування повинні мати системний характер і узгоджуватися із заходами щодо забезпечення еколого-економічної безпеки аграрного сектору.

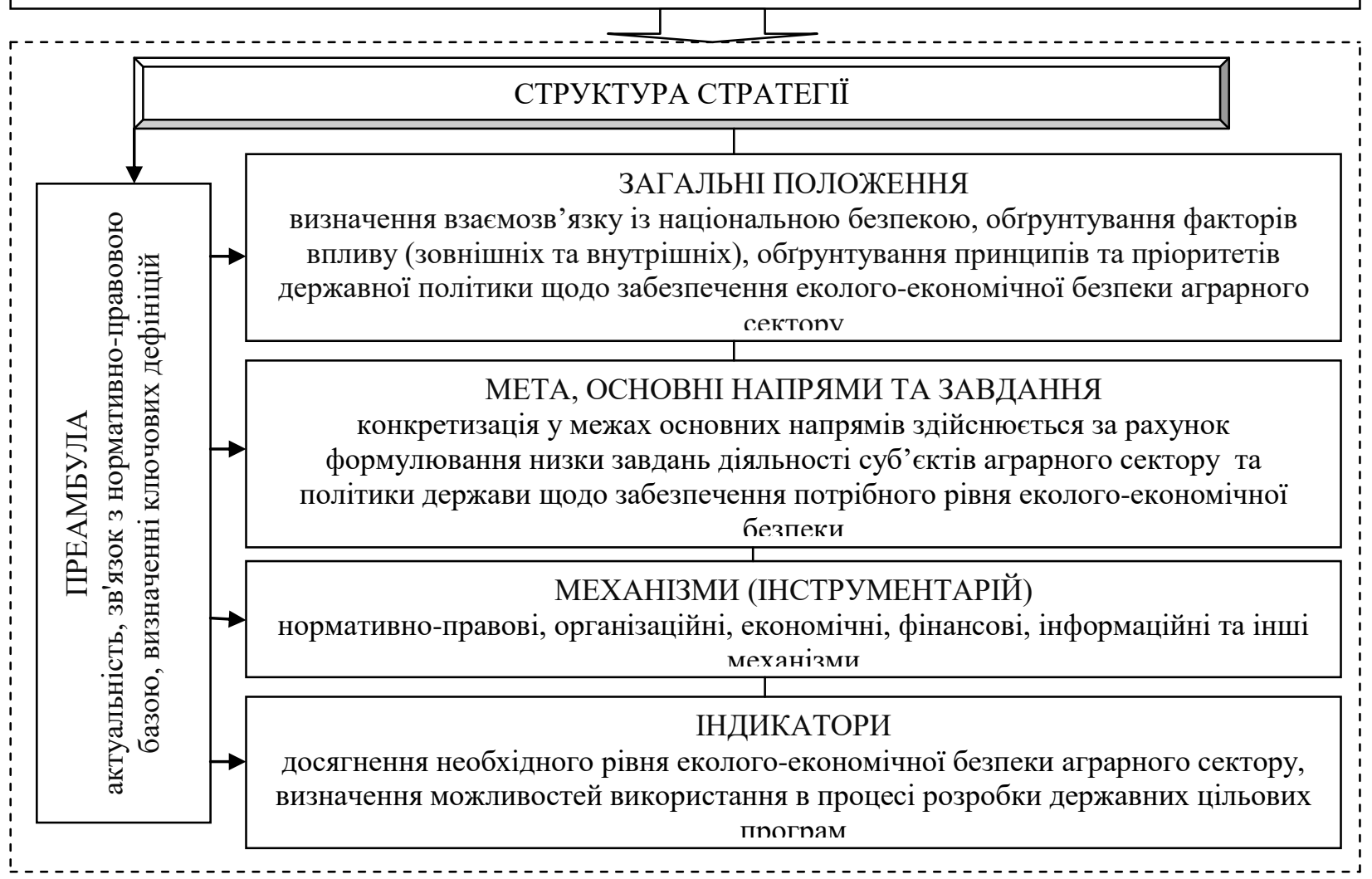

Рис. 1. Схематична інтерпретація складових стратегії еколого-економічної безпеки аграрного сектору в Україні

*Джерело: розроблено автором 
3 метою досягнення єдиного підходу до обгрунтування основних понять вони мають бути визначені наступним чином:

1) «еколого-економічна безпека» - це сукупність відповідних властивостей навколишнього середовища i створюваних цілеспрямованою діяльністю людини умов, за яких, 3 урахуванням соціально-економічних чинників i науково обгрунтованих допустимих навантажень на об'єкти біосфери утримуються на мінімально можливому рівні ризику антропогенний вплив на навколишне середовище і негативні зміни, що відбуваються в ньому, забезпечується збереження здоров'я, життєдіяльності людей і виключаються віддалені наслідки цього впливу для теперішнього і наступного поколінь;

2) «державний механізм регулювання еколого-економічної безпеки аграрного сектору» - сукупність методів, заходів, інструментів та важелів впливу на еколого-соціо-економічні відносини, що спрямовані на забезпечення фундаментальних засад забезпечення еколого-економічної безпеки аграрного сектору через збереження й відтворення природних ресурсів, залучених у господарський обіг, попередження або недопущення негативного впливу господарської діяльності на екосистеми, створення сприятливих умов для виробництва екологічно безпечної продукції й сировини;

3) «стратегія еколого-економічної безпеки аграрного сектору» систематизоване обгрунтування основ державної політики, спрямованої на забезпечення еколого-економічної безпеки аграрного сектору та комплексу практичних заходів щодо такого стану результатів виробництва, навколишнього середовища, при якому забезпечується попередження погіршення екологічного стану в країні та виникнення небезпеки для здоров'я i якості життя громадян [1-8].

II. Загальні положення.

Забезпечення еколого-економічної безпеки аграрного сектору, як предмет, має розглядатися у контексті реалізації державної аграрної політики та 
враховувати особливості національної еколого-економічної політики в державі. При цьому необхідно зважувати на те, що вона, за своїм змістом, має інтегративний характер, тобто містить умови поєднання політики, спрямованої на охорону навколишнього природного середовища і політики регулювання процесів раціонального користування природними ресурсами.

На процеси, пов'язані з розробкою та впровадженням політики екологоекономічної безпеки аграрного сектору, впливають як зовнішні, так і внутрішні фактори. До зовнішніх факторів, які представлені, насамперед процесом світового, глобального рівня відносять: зміну клімату та виснаження озонового шару; зростання збитків для екології від стихійних та техногенних катастроф; недостатній рівень міжнародної координації у питаннях переходу до моделі сталого розвитку людської цивілізації; зростання кількості населення планети при скороченні територій, придатних для проживання людей; деградація основних компонентів біосфери, яка проявляється, насамперед, як скорочення біологічного різноманіття, пов’язаного з цим зниження здатності природи до саморегуляції; зростання споживання природних ресурсів при одночасному скороченні їх запасів; спроби вирішення еколого-економічних питань як органічної складової регулювання загальносвітових проблем; війни та спроби вирішення міжнародних та міжнаціональних конфліктів із застосуванням військової сили.

До складу внутрішніх факторів, що впливають на процеси забезпечення еколого-економічної безпеки аграрного сектору належать: недостатня результативність державної системи регулювання, що вирішує завдання забезпечення еколого-економічної безпеки аграрного сектору за рахунок послаблення контрольних функцій органів регулювання в екологічній сфері; недостатній рівень організацій функціонування аграрного сектору при технологічній недосконалості; відносно низький рівень життя населення країни; остаточні явища загальної системної соціально-економічної кризи;

\footnotetext{
(C) Українська інженерно-педагогічна академія

(C) ГО «Школа адаптивного управління сочіально-педагогічними системами»

(C) Пищенко $O$.
} 
вкрай низький рівень еколого-економічної свідомості та еколого-економічної культури як пересічних громадян, так і суб’єктів аграрного сектору; низька ефективність функціонування існуючих механізмів регулювання процесами охорони навколишнього природного середовища та безпеки аграрного сектору; орієнтація аграрного сектору головним чином на ресурсоспоживання та добування ресурсів [2-5].

Діяльність, спрямована на забезпечення еколого-економічної безпеки аграрного сектору, має базуватися на сукупності комплексних принципах:

1) забезпечення рівноваги між динамічними аграрною i екологоекономічною системами та компонентами природи, що здійснюється завдяки саморегуляції основних характеристик чи структур, речовинно-енергетичного стану або складу;

2) інтеграція економічного й екологічного підходів до розвитку аграрного сектору;

3) забезпечення відповідальності суб’єктами аграрного сектору за раціональне та ефективне використання природних ресурсів, їх збереження $\mathrm{i}$ захист від деградації;

4) стратегічні напрями в системі забезпечення еколого-економічної безпеки аграрного сектору мають формуватися на основі взаємозалежності заходів, з одного боку, спрямованих на зміцнення стійкості аграрного сектору, 3 іншого, - на підвищення ефективності протидії екологічним ризикам та загрозам;

5) реалізація стратегічних напрямів має здійснюватися з урахуванням розмежування повноважень елементів між рівнями системи забезпечення еколого-економічної безпеки аграрного сектору з урахуванням координації їх діяльності;

6) своєчасність і відповідність вжиття запропонованих заходів;

7) своєчасна адаптація з урахуванням мінливих стратегічних пріоритетів 
щодо підвищення рівня і якості життя населення;

8) прийняття рішення у сфері стратегічного планування повинні мати системний характер і узгоджуватися із заходами щодо забезпечення екологоекономічної безпеки аграрного сектору [7-8].

III. Стратегічна мета, основні напрями та завдання державної політики еколого-економічної безпеки аграрного сектору в Україні.

Державна політика в Україні щодо забезпечення екологічно безпечного розвитку аграрного сектору, орієнтована на збереження безпечної для існування населення живої та неживої природи, навколишнього середовища, досягнення гармонійної взаємодії суспільства і природи, охорону, раціональне використання і відтворення природних ресурсів.

Виходячи з вищевикладеного, стратегічною метою державної політики у напрямку забезпечення еколого-економічної безпеки аграрного сектору $\epsilon$ забезпечення еколого-економічної безпеки країни, збереження природних систем, підтримання їхньої цілісності та життєзабезпечуючих функцій для сталого розвитку суспільства, покращення здоров'я та якості життя українських громадян шляхом розвитку екологічно безпечного виробництва.

До основних напрямів діяльності держави, спрямованих на забезпечення еколого-економічної безпеки аграрного сектору належать:

- удосконалення законодавчої, нормативно-правової та інституціональної бази й інструментів організаційно-економічного забезпечення екологоекономічної безпеки аграрного сектору;

- формування, розвиток і вдосконалення державної системи екологічного регулювання , орієнтованої на: зниження негативного впливу аграрного сектору на навколишне природне середовище або його запобігання; раціональне використання поновлюваних і невідновлюваних природних ресурсів; запобігання небезпечним природним явищам та оперативну ліквідацію їх наслідків; 
- розробка і реалізація організаційних, технічних і технологічних заходів для аграрного сектору, включаючи впровадження екологічно безпечних, ресурсозберігаючих i енергозберігаючих технологій, що забезпечують зниження техногенного навантаження на навколишнє природне середовище, а також раціональне використання природних ресурсів;

- розвиток системи екологічного моніторингу, а також наповнення фонду даних державного екологічного моніторингу (державного моніторингу навколишнього природного середовища) як основи для прийняття управлінських рішень з охорони навколишнього природного середовища;

- удосконалення системи стандартизації і сертифікації екологічно безпечного аграрного сектору, переробки, зберігання та транспортування продукції аграрного сектору;

- розроблення та прийняття державних та місцевих програм забезпечення еколого-економічної безпеки аграрного сектору [6-8].

IV. Механізми (інструментарій).

До інструментів державної політики еколого-економічної безпеки аграрного сектору належать насамперед ті, що дозволяють зміщувати акценти 3 процесу розробки політики на іï практичне здійснення, на удосконалення i можливості адаптації екологічного законодавства СС до українських реалій, зміцнення інституціонального потенціалу природоохоронної діяльності й створення ефективних інструментів еколого-економічної аграрної політики.

\section{Висновки i напрямки подальших наукових досліджень.}

Удосконаленню системи регулювання процесами еколого-економічної безпеки аграрного сектору покликана сприяти запропонована стратегія екологоекономічної безпеки аграрного сектору в Україні, яка має стати базовим документом стратегічного планування у напрямку розвитку еколого-соціоекономічної системи забезпечення еколого-економічної безпеки аграрного сектору, який визначає комплекс взаємопов'язаних пріоритетів, цілей, завдань

\footnotetext{
(C) Українська інженерно-педагогічна академія

(C) ГО «Школа адаптивного управління сочіально-педагогічними системами»

(C) Пищенко $O$.
} 
та заходів. Для реалізації стратегії необхідно виконати комплекс завдань: визначити основні параметри екологічно безпечного стану аграрного сектору; ідентифікувати пріоритети еколого-економічної політики щодо цілей забезпечення еколого-економічної безпеки аграрного сектору; обгрунтувати шляхи і способи досягнення завдань забезпечення еколого-економічної безпеки аграрного сектору; сформувати комплекс заходів, що забезпечують досягнення визначених цілей і завдань; визначити необхідні ресурси для реалізації визначених завдань, а також умов і чинників, що забезпечують найбільшу ефективність їх використання; забезпечити ефективну організацію моніторингу реалізації документів стратегічного планування в забезпеченні екологоекономічної безпеки аграрного сектору. Реалізація стратегії екологоекономічної безпеки аграрного сектору має забезпечуватися шляхом прийняття на іiї основі нових законодавчих та інших нормативно-правових актів, внесення змін і доповнень до правових актів у сфері аграрного сектора та охорони навколишнього природного середовища, а також розроблення Державної програми забезпечення еколого-економічної безпеки аграрного сектору в Україні на 2018-2022 pp.

\section{Використана література:}

1. Буркинський Б. В., Галушкіна Т. П., Реутов В. Є. «Зелена»економіка крізь призму трансформаційних зрушень в Україні: монографія. Одеса: Підприємство «Фєнікс», 2011.348 с.

2. Гайдуцький I. П. Інвестування низьковуглецевої економіки: теорія, методологія, практика: монографія. Київ: Інформаційні системи, 2014. 373 с.

3. Галушкіна Т. П., Костецька К. О. «Зелена» економіка в секторальній моделі розвитку. Економічні інновації. 2012. Вип. 48. С. 68-77.

4. Мельник Л. Г., Кубатко О. В. Ефективність використання природноресурсного потенціалу України та передумови формування «зеленої» економіки. Вісник соціально-економічних досліджень. 2013. № 3. С. 169-174.

5. Потапенко В. Г. Стратегічні пріоритети безпечного розвитку України на засадах «зеленої економіки»: монографія. Київ: НІСД, 2012. 359 с.

\footnotetext{
(C) Українська інженерно-педагогічна академія

(C) ГО «Школа адаптивного управління сочіально-педагогічними системами»

(C) Пищенко $O$.
} 
6. Саблук П. Т. Інноваційна модель розвитку аграрного сектору економіки України та роль науки в $\dddot{1}$ становленні. Проблеми інноващійноінвестииійного розвитку. 2011. № 2. С. 200-208.

7. Ходаківська О. В. Екологізація аграрного виробництва: монографія. Київ: ННЦ ІАЕ, 2015. 350 c.

8. Ходаківська О. В. Екологізація аграрного виробництва: сучасні виклики та перспективи розвитку. Економіка АПК. 2015. № 5. С. 43-47.

\section{References}

1. Burkynskyi B. V., Halushkina T. P., and Reutov V. Ye. (2011), "Zelena" ekonomika kriz pryzmu transformatsiinykh zrushen v Ukraini ["Green" economy through the lens of transformational shifts in Ukraine]. Odesa: Feniks, 348 p. [Ukraine].

2. Haidutskyi I. P. (2014), Investuvannia nyzkovuhletsevoi ekonomiky: teoriia, metodolohiia, praktyka [Investment low-carbon economy: theory, methodology, practice]. Kyiv: Informatsiini systemy, 373 p. [Ukraine].

3. Halushkina T. P. and Kostetska K. O. (2012), "Zelena ekonomika v sektoralnii modeli rozvytku" ["Green economy in sectoral development model"], journal Ekonomichni innovatsii, [Economic innovation], vol. 48, pp. 68-77 [Ukraine].

4. Melnyk L. H. and Kubatko O. V. (2013),"Efektyvnist vykorystannia pryrodno-resursnoho potentsialu Ukrainy ta peredumovy formuvannia zelenoi» ekonomiky" ["The efficiency of natural-resource potential of Ukraine and the prerequisites for the formation of "green" economy"], journal Visnyk sotsialnoekonomichnykh doslidzhen [Bulletin of socio-economic research], vol. 3, pp.169-174 [Ukraine].

5. Potapenko V. H. (2012), Stratehichni priorytety bezpechnoho rozvytku Ukrainy na zasadakh zelenoi ekonomiky [Strategic priorities the safe development of Ukraine on the principles of green economy]. Kyiv: NISD, 359 p. [Ukraine].

6. Sabluk P. T. (2011), "Innovatsijna model' rozvytku ahrarnoho sektoru ekonomiky Ukrainy ta rol' nauky v ii stanovlenni" ["Innovative model of develop ment of the agrarian sector of Ukraine's economy and the role of science in its formation"], journal Problemy innovatsijno investytsijnoho rozvytku [Problems of innovation and investment development], vol. 2, pp. 200-208 [Ukraine].

7. Khodakivska O. V. (2015), Ekolohizatsiia ahrarnoho vyrobnytstva [Ecologization of agricultural production]. Kyiv: NNTs IAE, 350 p.[Ukraine].

8. Khodakivska O. V. (2015), "Ekolohizatsiia ahrarnoho vyrobnytstva: suchasni vyklyky ta perspektyvy rozvytku" ["Ecologization of agrarian production: modern challenges and perspectives of development"], journal Ekonomika APK [APK economy], vol. 5, pp. 43-47 [Ukraine].

\footnotetext{
(C) Українська інженерно-педагогічна академія

(C) ГО «Школа адаптивного управління сочіально-педагогічними системами»

(C) Пищенко $O$.
} 


\section{ПИЩЕНКО АЛЕКСАНДР,} кандидат экономических наук, Национальный университет «Черниговская политехника», г. Чернигов, Украина

\section{КОНЦЕПТУАЛЬНО-МЕТОДОЛОГИЧЕСКИЕ АСПЕКТЫ ФОРМИРОВАНИЯ СТРАТЕГИИ ОБЕСПЕЧЕНИЯ ЭКОЛОГО- ЭКОНОМИЧЕСКОЙ БЕЗОПАСНОСТИ АГРАРНОГО СЕКТОРА}

Аннотация. Предложены составляющие стратегии экологоэкономической безопасности аграрного сектора в Украине, ключевой целью которой является определение модели действий и средств системы обеспечения эколого-экономической безопасности аграрного сектора, разработка основных направлений, форм, методов и инструментов достижения стратегических целей; аргументировано, что данная стратегия должна включать пять разделов (1. Преамбула. 2. Общие положения. 3. Цель, основные направления и задачи. 4. Механизмы. 5. Индикаторы), реализация которых предполагает объединение усилий властных структур и общества на уровне государства, регионов и местного самоуправления. Для реализации стратегии необходимо выполнить комплекс задач: определить основные параметры экологически безопасного состояния аграрного сектора; идентифицировать приоритеты экологоэкономической политики в отношении целей обеспечения экологоэкономической безопасности аграрного сектора; обосновать пути и способы достижения целей обеспечения эколого-экономической безопасности аграрного сектора; сформировать комплекс мероприятий, обеспечивающих достижение определенных целей и задач; определить необходимые ресурсы для реализации определенных задач, а также условий и факторов, обеспечивающих наибольшую эффективность их использования; обеспечить эффективную организацию мониторинга реализации документов стратегического планирования в обеспечении эколого-экономической безопасности аграрного сектора. Механизм реализации стратегии предполагает объединение усилий властных структур и общества на уровне государства, регионов и местного самоуправления в направлении координации стратегии действующим комплексными целевыми программами и осуществления мониторинга еe реализации на основе установления целевых показателей. Информационная и информационно-аналитическая поддержка реализации этой стратегии осуществляется при координирующей роли соответствующего Министерства за счет привлечения информационных ресурсов заинтересованных органов государственной власти и государственных научных учреждений.

\footnotetext{
(C) Українська інженерно-педагогічна академія

(C) ГО «Школа адаптивного управління сочіально-педагогічними системами»

(C) Пищенко $O$.
} 
Ключевые слова: аграрный сектор, эколого-экономическая безопасность, стратегия, обеспечение, государственная политика.

PISHCHENKO ALEXANDER,

Candidate of Economic Sciences,

National University

"Chernihiv Polytechnic",

Ukraine

\title{
CONCEPTUAL AND METHODOLOGICAL ASPECTS OF FORMATION OF STRATEGY FOR ENVIRONMENTAL AND ECONOMIC SAFETY OF THE AGRICULTURAL SECTOR
}

\begin{abstract}
The components of the strategy of ecological and economic security of the agricultural sector in Ukraine are proposed, the key purpose of which is to determine the model of actions and means of the system of ecological and economic security of the agricultural sector, development of main directions, forms, methods and tools to achieve strategic goals; it is argued that this strategy should include five sections (1. Preamble. 2. General provisions. 3. Purpose, main directions and tasks. 4. Mechanisms. 5. Indicators), the implementation of which involves the joint efforts of government and society on levels of the state, regions and local self-government. To implement the strategy it is necessary to perform a set of tasks: to determine the main parameters of the environmentally safe state of the agricultural sector; identify the priorities of environmental and economic policy in relation to the objectives of environmental and economic security of the agricultural sector; substantiate the ways and means of achieving the objectives of environmental and economic security of the agricultural sector; to form a set of measures to ensure the achievement of certain goals and objectives; identify the necessary resources for the implementation of certain tasks, as well as conditions and factors that ensure the greatest efficiency of their use; to ensure effective organization of monitoring the implementation of strategic planning documents in ensuring the environmental and economic security of the agricultural sector. The mechanism for implementing the strategy involves combining the efforts of government agencies and society at the state, regional and local governments to coordinate the strategy with existing comprehensive target programs and monitor its implementation based on targets. Information and information-analytical support for the implementation of this strategy is provided by the coordinating role of the relevant Ministry through the involvement of information resources of interested public authorities and public research institutions.
\end{abstract}

Keywords: agricultural sector, ecological and economic security, strategy, provision, state policy.

(C) Українська інженерно-педагогічна академія

(C) ГО «Школа адаптивного управління сочіально-педагогічними системами»

(C) Пищенко $O$. 